\title{
Polls and the Political Process: The Use of Opinion Polls By Political Parties and Mass Media Organizations in European Post- Communist Societies (1990-95)
}

\author{
Matt Henn. \\ Journal of Communist Studies and Transition Politics, \\ Vol. 13 (3), pp. 127-147. 1997.
}

DOI: 10.1080/13523279708415355

\begin{abstract}
Opinion polling occupies a significant role within the political process of most liberal-capitalist societies, where it is used by governments, parties and the mass media alike. This paper examines the extent to which polls are used for the same purposes in the post-communist countries of Central and Eastern Europe, and in particular, for bringing political elites and citizens together. It argues that these political elites are more concerned with using opinion polls for gaining competitive advantage over their rivals and for reaffirming their political power, than for devolving political power to citizens and improving the general processes of democratization.
\end{abstract}

Matt Henn is a Senior Lecturer in Social Science Research Methodology at the Department of Politics and Economics, The Nottingham Trent University. He has a doctorate in Politics which compares the development of opinion polls in latecapitalist and post-communist societies, and has published in this area. He is grateful to both Larry Wilde and to Mike Young for comments made on earlier versions of this paper. Thanks is also given to all his colleagues in Poland, the Czech Republic, Hungary, Romania and Bulgaria, and especially to Cenek Adamec, Piotr Kwiatkowski, Petre Datculescu and Ognian Shentov, each of whom provided invaluable help in organizing the fieldwork for the research. 
The intervention that opinion polls have made into the political process within liberal-capitalist societies is pervasive, often problematic, and well documented. ${ }^{1}$ Yet, whilst political opinion polling occupies a well-entrenched position within many such countries, the same cannot be said for the newly emerging post-communist societies of Central and Eastern Europe. Prior to the collapse of communist regimes throughout the region, polling was limited in terms of its activities, the scope of issue coverage, and its ability to measure public opinion effectively. ${ }^{2}$ This article focuses primarily on the use made of opinion polls in post-communist societies by a range of political agents, including governments, political parties, and mass media organizations, in order to provide an account of the role of polls within the general processes of transition currently underway in these newly democratizing countries. It is based almost entirely upon semi-structured in-depth interviews with both opinion polling companies, and with users of the polls. ${ }^{3}$ The interviews were designed to help identify the rationale for opinion poll usage by these political agencies, how the information was built into policy and programmes, and the degree of importance attached to polls in general activities. It became clear during the course of the interviews that whilst opinion polls provided the opportunity for these political actors to articulate the views, needs and aspirations of the citizenry on political matters, ultimately polls were utilized not to establish some form of participatory 'direct democracy', but instead primarily to help political elites gain competitive advantage over their rivals and maximize their political power.

\section{Polls and The Political Process}

Schumpeter ${ }^{4}$ counterposes two extremes of representative democracy which can be used to articulate the relationship between opinion polls and the processes of democratization in capitalist societies, and to understand the use made of polls by governments, political parties and the mass media organizations in post-communist societies. First, he conceptualizes a 'classical doctrine of democracy' characterized as '...that institutional arrangement for arriving at political decisions which realizes the common good by making the people itself decide issues through the election of individuals who are to assemble in order to carry out its will' ${ }^{5}$ This model broadly reflects Gallup's hopes for polls as tools through which citizens could gain direct access to (and ultimately influence over) policy-makers and other political elites. ${ }^{6}$ Gallup's preference was for political systems which were built upon the principles of direct democracy, where the opinions and priorities of the electorate determined policy agendas, and where elected politicians were responsive and accountable to the citizenry at all times during the electoral cycle. In the absence of such political arrangements, he advocated the use of opinion polls in decision-making processes which could 
formulate and express the views of the mass electorate, and serve as a channel of communication between the governed and the government. He acknowledged that in representative democracies it is elites which wield political power, but claimed polls were a key element of popular input which elected representatives would have to take into account in decision-making; essentially he maintained that polls could help to redress the imbalance of power in society in favour of voters. In this scenario, polls could serve three vital functions: firstly as mechanisms to articulate the general will of the people; secondly to help facilitate the decentralization of political power from elites to mass civil society; and thirdly to combat the influence of dominant groups in society. Such arguments form the basis of a populist model of opinion polling and political democratization.

An alternative view of the relationship between opinion polls and policy-making in capitalist societies can be understood through Schumpeter's opposing extreme of competitive elitism. This defines democracy as "...an institutional arrangement for arriving at political decisions in which the individuals acquire the power to decide by means of a competitive struggle for the people's vote". ${ }^{7}$ He claims that citizens are an ignorant and apathetic mass, which will inevitably be manipulated. The remoteness of the world of international and national affairs from the lives of most people leaves them in a very weak position to make sound judgments about competing ideologies and policies. Moreover, the general susceptibility of individuals, and their vulnerability to the pressures of interest groups and the mass media, undercuts any independent basis for political thought. In addition, the increasing use by politicians of the techniques of advertisers, erodes further any notion that the 'sovereign people' are, or could be, the source of, and check on the powers of the 'sovereign state'. 8 Furthermore, Schumpeter claimed that the notion of 'popular sovereignty' was ambiguous. He had a low estimation of the political, intellectual and objective capacities of the average citizen, and argued that the electorate should only have minimal political involvement, sufficient to legitimate the right of competing political elites to rule. There should be a clear division of labour between voters and elected representatives, and the former should avoid trying to instruct or influence representatives, to allow leaders to define the parameters of public policy efficiently and unimpeded.

The implications for polls which this model of competitive elitism holds is that rather than reacting to voter's concerns through opinion polls, policy-makers should govern responsibly according to their own judgements. This position was one advocated by Lindsay Rogers, ${ }^{9}$ Gallup's chief adversary during the early years of polling in the USA. His chief concern was over the limitations of mass publics as both facilitators of the political process and as designators of policy in representative democracies. In arguing his case, he maintained that politicians and other political representatives should avoid mistaking the short-range view of the mood of voters, for the long-term conception of a 'public interest' which is not readily discernible through opinion polls. According to Rogers, measuring the 'public interest' involves taking into consideration the opinions, values and 
interests of the entire Commonwealth, referred to by Lippmann as "...the People, as a community of the entire living population, with their predecessors and successors". ${ }^{10}$ Voters however, have a narrower social and historical base than the commonwealth, and cannot therefore claim to represent it. What is more, voters' inclinations are towards self-preservation in promoting their own interests, and they demonstrate a tendency towards hasty and ill-considered actions which may lead to unwise or unjust government policies.

From this perspective, these problems are compounded by the lack of competence of public opinion in political matters. Roll and Cantril ${ }^{11}$ claim that the public as voters lack the capacity to effectively direct the actions of political representatives, because they do not possess the technical, scientific or general awareness of all the facts concerning public policy, neither are they in a position to conceptualize the implications of adopting particular policy positions. Therefore, the "...public obviously cannot be expected to be informed and up-to-date in its understanding of complex issues, the implications of alternative courses of action, nor the advantages of specific instrumentalities by which a policy is affected". ${ }^{12}$ Essentially this argument maintains that in most circumstances, public opinion is passive, and depends for its articulation upon a reaction to problems and policies presented to it by policy-makers and opinion leaders. Consequently, the results of opinion polls do not necessarily demonstrate the views, aspirations, interests and policy-demands of the electorate; instead, they reflect the outcome of the struggle of competing ideologies and influential groups, organizations and classes in society who have influence over the pollsters in terms of the subject and the form of the questions asked. Policy-makers should therefore avoid legislating on the basis of polling data alone.

\section{Post-communist Governments and Polls}

As is the case in liberal-capitalist societies, governments in post-communist countries find great value in utilizing opinion polling data (particularly for policy development) and in fact are the major sponsors of such research there. For example, in Hungary, polls have in the past been used regularly to ask the public how they rate the various government and state institutions, and to ascertain the level of confidence that people have in these. In addition, governments are interested in identifying citizen's satisfaction with the new political system, and what steps they would like decision-makers to take in order to improve the current political arrangements. ${ }^{13}$ Polls are also used to help define the shape and direction of individual policies. According to Somogyi (an opinion pollster), the government polled the public on the issue of land reform in 1991 in order to gauge the level of support for the proposed legislation, and the form that it should take (either as shares, or in terms of returning the actual land to its previous owner-families). ${ }^{14}$ 
Polls have been used extensively in this way by governments in Romania, Bulgaria, (the former) Czechoslovakia and Poland. Opinion pollster Datculescu claims that polls perform a significant range of functions for governments in post-communist Romania. Here, they are often utilized as a means of auditing public opinion, and particularly the main concerns of, and problems confronting, the public. Thus, his own company, IRSOP, was commissioned by Prime Minister Roman in 1990 to identify the extent to which the government's plans for economic and market reform had the support of the public, and indeed, the final programme drew heavily on the results of these polls. Furthermore, polls were sponsored by the government in 1995 as part of the general debate concerning the type of electoral system (majoritarian- or proportional-based) that should be devised for the next election. Datculescu also notes that governments place significant emphasis on opinion polls in the more general area of policy-development, including for instance: the technical aspects of privatization policies; the development of social policies to soften the effects of national transition programmes on the elderly; and rural/urban migration policies. One early example of the intervention of polling within the general processes of government in Romania, is cited by Datculescu as following a series of demonstrations in January 1990, outside the headquarters of Petre Roman's provisional government. The main demands of the demonstrators were for the Communist Party to be banned, and for its leading members under Ceausescu to be executed. The government, which had recently outlawed the death penalty, were unsure as to how representative of public opinion the demonstrators and their demands actually were. IRSOP conducted an opinion poll which concluded that in fact the demonstrators' demands were regarded by the general public as anathema to democracy, and more in line with the methods of the former Ceausescu regime. By the time the data was available however, the issue had lost much of its salience, and the demonstration largely dissipated. Nonetheless, following discussions with Prime Minister Roman, Datculescu claims that the polls performed a significant role in confirming within government circles, that they had the support of public opinion behind them in their refusal to cede to the demonstrators' demands. ${ }^{15}$

A series of polls were conducted by the Bulgarian Socialist Party government during the water crisis of 1995. Polls had suggested that the situation was considered as particularly acute by the public, but the government were faced with a dilemma in resolving the water shortages: a solution seemed to lie with the development of a new water pipeline, but these plans were thought likely to entail negative ecological consequences for particularly the mountain region adjacent to Sofia; furthermore, a similar programme begun in 1990 had been met with citizens' demonstrations and riots organized by Ecoglasnost, and the government were concerned not to precipitate copy-cat actions. Polls however, suggested that mass opinion prioritized the solution of the water crisis over environmental concerns. The issue for the government at this stage remains as how best to action the public's demands without compromising both their environmental agenda, and the ecological system 
itself. In this, polls may perform a problem-identification role, by informing the government of mass sentiment on the matter, but the issue of problem-solution is too complex a process for polls by themselves to solve. ${ }^{16}$

In (former) Czechoslovakia, Herzmann ${ }^{17}$ reports that his institution's polls (UVVM) were commissioned by the Presidential Office for a variety of reasons between 1990 and 1991. In the first place, polls enabled the president's advisory team to maintain close contact with the public, and to develop legislation from a position which was informed by public opinion. Thus, in the early months after the Velvet Revolution, polls were conducted with the specific objective of developing democratic mechanisms (such as the electoral system) on the basis of consulting with the public via the polls. Secondly, polls were frequently used in parliamentary debate to legitimize policy positions, set the political agenda, or else to de-sensitize issues. Hartl, of polling agency STEM, claims that the Czech Parliament commissioned a series of opinion polls on the Bohemian, Moravian and Slovak national questions prior to a vote on the issue in February 1991 which influenced the outcome of the debate:

We prepared the results of the surveys before Parliament's plenary session on these topics. We prepared a report for all MP's two weeks before. Debate until that time was every emotional. Survey results de-sensitized the debate, and showed that the population were relaxed and calm about these issues. The topic then became pushed aside from the political agenda because of our survey. It showed nationalism was not really backed by the population. ${ }^{18}$

Polls are sometimes used in an equivalent way in Poland. In early 1991, proposals were raised in Parliament which were designed to outlaw abortion. In the interim period before the issue was brought to a vote, the government decided to hold a series of consultations with the public, in order to gauge the mood on the issue. However, according to opinion pollster Kwiatkowski (CBOS), the process was '...not a real consultation because a lot of priests imposed letters against abortion upon their parishes, and a lot of pressure was put upon congregations'. ${ }^{19}$ The results of an opinion poll however published on the day of the parliamentary vote, contradicted the findings of these 'consultations', and suggested that the majority of the public did not agree with the anti-abortion lobby. As a result, the Polish Parliament voted not to allow a change in the law at that time. However, opinion pollster Nowotny (Demoskop) points out the problems of using polls in this way: 'On the question of the law against abortion, the danger is that the poll results are taken as an absolute, and the poll will be taken as a 'surrogate' for a referendum, and as an argument in the political dispute'. ${ }^{20}$ Some pollsters then are clearly wary that politicians in the new post-communist societies often place too heavy a reliance on opinion polls, using them as a tool for developing and implementing policy rather than as a feedback mechanism to monitor the electorates' views. 
This discussion has demonstrated the ways in which polls both feed directly into the process of defining democratic structures and institutions in post-communist societies, and also help to ensure that political elites are kept in touch with people's views, needs and aspirations. It also suggests that polls may be utilized in governmental and parliamentary debate to influence the course of policymaking and legislation.

\section{Polls and the Political Parties}

Political parties are also important users of the polls. However, the nature of the party system is such, that it largely impedes the development of strong and sustained party-pollster links of the kind that are noticeable in countries like Britain. In Poland for instance, the proliferation of parties results in a situation where demand for the polls as a source of political intelligence to help market the parties cannot be satisfied because '...there are thousands of parties, and they are usually too poor to buy polls'. ${ }^{21}$ The same is the case in Romania, Bulgaria and in Hungary, where there are few parties with sufficient financial resources to commission polls. This is a major fetter on the development of the industry, although the larger parties do frequently sponsor such opinion research, especially on poll omnibuses. ${ }^{22}$ Furthermore, the parties often make substantial use of secondary polling data. Hoscalet notes that the election campaign team for the Civic Forum in (former) Czechoslovakia conducted a detailed analysis of the polling results generated by his company, AISA, in order to develop a campaign strategy for the general election in June $1990 .{ }^{23}$ Moser, president of the Agrarian Union, states that in Bulgaria it is common practice for smaller parties like her own, to rely on secondary polling data because of the prohibitive costs of commissioning their own primary data. Ironically, she claims that at the December 1994 general election, her party, along with many others, utilized polling data reported in a campaign document produced by rivals, the Bulgarian Socialist Party. ${ }^{24}$

The uses to which polls are put by the parties in these post-communist societies, largely reflect those for parties found in liberal capitalist societies. ${ }^{25}$ These include monitoring the dynamics of electoral opinion, targeting specific voter groups, and helping to build electoral strategies. Kivu recalls that from the time of Ceausescu's fall to the middle of 1992, almost all of his company IMAS' work in Romania focused on political issues, and much of it for political parties (although since that time, the balance has been more toward market research). This political polling research involves measuring general voting intentions, reactions of the public to specific political events, the authority of individual party spokespersons, together with the values and demographics of different voter groups to try to identify electoral constituencies for party clients. Furthermore, prior to the general election in Romania in 1992, polls were commissioned to ascertain the issue priorities of the electorate and of targeted groups, with the intention of modifying and shaping the image of these parties. ${ }^{26}$ Polls are used in similar ways in Bulgaria. Gjuzelev maintains that polls have been utilized by his 
Democratic Party to assist the establishment of an identity amongst the electorate. Regarding itself as a naturally right-wing party, it found itself largely devoid of any social base within the electorate because of the relatively small size of the Bulgarian middle class (only about 3\% of the population), and the virtual absence of any large, private industrial enterprises. Consequently, polls were undertaken in an attempt to solve this identity crisis, and revealed that it would be electorally beneficial to target small land-holders and those voters whose descendants had lost their land, industry and dwellings during the communist period. ${ }^{27}$

Another major area of polling research undertaken by the parties is geared toward developing electoral strategies. For instance, prior to the 1992 Romanian general election, the polling agency CIS were asked by the Democratic Convention to gauge the distribution of votes between its member parties. The data was to be used in preparatory dialogue to organize the number of places that each party should have on the coalition's electoral list, as well as their rankings on the list. CIS negotiated only with the dominant Peasant Party, who largely ignored the data because the results did not reflect their interests. Consequently, the final list was significantly more favourable to the Peasant Party than their position within the poll actually warranted, and led to intense argument between the party and its coalition partners. ${ }^{28}$ These developments helped to inform the Liberals within the Democratic Convention in 1993 that they should consider possibly leaving the coalition. Polls conducted by IMAS played a significant role in this reasoning, and ultimately in the fragmentation of the National Liberal Party. ${ }^{29}$ The majority within the leadership of the Liberals decided to leave the Democratic Convention after studying IMAS' polling data which suggested it would be politically expedient to do so, although one wing of the party opted to remain within the coalition. The National Liberal Party then split, with one of the groupings deciding to re-join the Convention coalition. Meanwhile, the group which had originally stayed in the Convention then decided to leave and form its own independent Liberal Party. Later, in January 1995, the Liberal PL93 commissioned IMAS to assess the impact of their possibly leaving the then four-party Liberal Coalition platform within the Democratic Convention, and standing instead as an independent party. Polls suggested that this strategy would gain the party a $20 \%$ share of the vote, and consequently, PL93 left the Democratic Convention later that year.

In Bulgaria, secondary polling data has been utilized by the Popular Union (an alliance of the Democratic Party and the Agrarian Union) to aid the focusing of their general campaigning strategy after results showed that the public had little awareness of who it was, which parties comprised it, and what it stood for. Furthermore, polling data suggested that crime was of crucial concern to voters, and consequently, in the final 48 hours of the 1992 general election, this issue became the primary campaign theme for the Popular Union. ${ }^{30}$ This coalition also organized a special strategy conference for the municipal and mayoral elections in April 1995, which had a specific focus on the electoral 
importance of opinion polling, and how to use its results in campaigning. A number of West European and North American electoral consultants and opinion pollsters addressed the conference, including the 'Westminster Foundation' (a right-wing organization), political advisors to the German CDU, and others. ${ }^{31}$

For the Bulgarian Socialist Party (BSP), polls played a significant role in guiding their perception of, and orientation to, the government of technocrats which replaced the UDF administration in December 1992. Initially the BSP had given qualified support to the government, but National Committee member, Miroslav Popov claims that their position changed dramatically following a series of opinion polls which suggested that the public were in favour of a strong, singleparty-based government. Consequently, the BSP decided to withdraw their support in parliament for the government, which facilitated the elections in December 1994. As Popov concludes, in this process, '...polls assist [the] formulation of political strategy as an important tool'. ${ }^{32}$ During the 1994 general election campaign, the BSP made substantial use of their long-standing relationship with the polling company British-Balkan Social Surveys (BBSS), and commissioned a series of large-scale polling studies, the results of which were compiled into a campaigning document and sent out to activists three weeks before the election. The report identified 100 key geographic areas for focused campaigning, as well as which target groups should be singled out for special consideration (such as highly educated workers, and women working at home), and how best to win their support (through for instance which themes and policies to prioritize, and how to present them). As Popov explains, the campaign was not dictated by the polls, but the data performed a significant role in its development and focus.

However, whilst polls provide obvious benefits to the political parties in their general campaigning strategies and political marketing, their usage for these purposes is often a source of significant controversy, usually because it is typically only the larger parties who have the resources to commission them. Consequently, smaller parties often attempt to discredit political opinion polls on the grounds that they facilitate unfair electoral competition, and help contribute to the continued dominance of the larger parties. In countries where the electoral system sets a minimum percentage threshold of voter support before a party can gain representation in parliament, this is a particularly contentious area for polling. Thus, Gjuzelev, claims that theoretically, in countries like Bulgaria where such electoral rules apply, polls could perform a useful function for smaller parties: where there are for instance 120 parties vying for parliamentary representation at an election (Bulgaria 1994), polls can help create a bandwagon for a party if the data demonstrates that it has more support than the minimum electoral threshold (4\% in this case), by suggesting to voters that their support for that party would not result in a 'wasted vote'. Whilst opinion polls reported publicly in the media might assist some smaller parties in this way, their lack of resources implies that they are unable to 
commission their own polls in an attempt to generate such bandwagons. Meanwhile, Gjuzelev claims that the larger Union of Democratic Forces (UDF) is able to sponsor and then manipulate their own polls for electoral gain as they attempted at the general election in 1994; the UDF claimed on a number of occasions that their polls indicated that the Peoples Union (PU) and other small, anti-BSP parties would achieve less votes than that required to cross the $4 \%$ electoral threshold, and that voters should therefore support the UDF if they wanted to help defeat the BSP. In the event (and contrary to the claims of the UDF) three such parties and coalitions (including the PU) gained sufficient votes to enter the parliament independently of both the dominant UDF and BSP parties. ${ }^{33}$ In a similar example, Anastassia Moser, president of the Agrarian Union, suggests that there is widespread evidence of collusion between the former communist BSP, and the polling agency BBSS in trying to disorientate their rivals. This party-pollster alliance has a historical basis to it, in that the BBSS is the reorganized, former state-polling institute National Public Opinion Centre, which operated under the command of the communist regime during Ceausescu's era. Consequently, there are significant and long-standing links between the leading personnel in both organizations. Moser claims that BBSS was engaged in a propaganda-based campaign to create uncertainty and divisions within the Popular Union (of which her Party was a member) by releasing a series of poll results in the run-up to the 1994 Bulgarian general election which indicated that in coalition with the Democratic Party, they would achieve only $3 \%$ of the vote, but on their own, the Agrarian Union would pass the $4 \%$ electoral threshold, with $5 \%$. These results from BBSS contradicted other opinion poll findings. In the event, her party stayed with the coalition, which ultimately gained $6.5 \%$ of the votes, and 18 seats in parliament. $^{34}$

Allied to these problems is the criticism and scepticism that both political parties and the public have of any close associations that pollsters may have with the political parties. According to Somogyi, this is a hang-over from the communist era, where polling institutes were usually seen as an information-gathering appendage of the state, and as such a propaganda instrument of the MarxistLeninist parties:

Pollsters which are associated with a particular party are distrusted. For instance, the Meridian polling organization are accused of being in contact with the biggest opposition party, the Free Democrats. So people don't believe their results. And (the) state-owned organization is still accused of being associated with the old Communist Party. This company is the Hungarian Institute for Public Opinion. Their leaders were members of the Party. And if they had resigned, it was only to change direction with the way the wind blows. So they are still perceived as Party members. ${ }^{35}$

In (former) Czechoslovakia, the polling company Demoskopy was criticized for similar reasons. Its founder was both a former director of the state-owned polling institute UVVM, as well as a candidate for the Socialist Party at the June 1990 elections. The share of public support reported for the Socialist 
Party was consistently higher in Demoskopy's polls than in any other institute's polls. Opinion pollster Herzmann claims that this is due to the biased nature of Demoskopy's field-interview force, which was recruited through the Socialist Party's newspaper.

Similar problems arise in Romania, where '...the election returns [in 1992] baffled the expectations of most analysts and contradicted the forecasts of all but one Romanian pollster'. ${ }^{36}$ Only IRSOP correctly predicted victory for both Iliescu and for his National Democratic Salvation Front all the other pollsters' forecasts were that Constantinescu and the Democratic Convention would be the likely winners. ${ }^{37}$ However, Sandu notes that even IRSOP's record was inconsistent: of the two polls they conducted, only the second correctly identified the eventual presidential and parliamentary victors, yet the poll results were significantly different statistically from the final voting results. ${ }^{38}$ Furthermore, throughout the campaign period, there was significant variation recorded in the results of individual pollsters, as well as across polling agencies. ${ }^{39}$ Sandu claims that one source of blame for these polling failures lies in the nature of the interview teams employed. ${ }^{40}$ IRSOP, for instance recruited its fieldworkers from the Research Institute for Youth Problems, which had been established by, and was accountable to, the Central Committee of the communist youth organization under Ceausescu's reign. Sandu, vice-president of the Romanian Sociological Association, claims that it was therefore generally acknowledged to be left-wing (hence the strong showing for the NSDF in its polls). However, IMAS' interviewers were recruited through the right-wing weekly ' 22 ', the journal of the Group for Social Dialogue, which was active within the Democratic Convention. Both polling agencies have replaced their fieldwork teams since the 1992 general elections, following criticism from both the general sociological community in Romania and from the media there. ${ }^{41}$

One of the most critically received party-pollster associations reported during the various research visits conducted for this study is that between the Bulgarian Socialist Party (BSP), and the polling agency British-Balkan Social Surveys (BBSS). ${ }^{42}$ However, it is not entirely clear whether or not there is any direct collusion between the two in terms of massaging and manipulating poll results to create a bandwagon for the BSP in elections. Certainly, at the 1991 general election, BBSS were the only polling agency to predict (incorrectly) a victory for the former communists, and in 1994, their forecast of the final BSP margin of victory was both higher than other pollsters' pre-election polls, and than that actually achieved by the Party. ${ }^{43}$ Furthermore, there is intensive criticism of this relationship by both opposition parties and by anti-socialist newspapers. Gjuzelev, for instance claims there is a triangular network of deception on behalf of the BSP, which includes the party, pollsters, and some media organizations: the largest circulation daily newspaper, '24 Hours' is a supporter of the BSP and arch-critic of the UDF, reporting only polls conducted by BBSS; and a subsidiary of BBSS, Mediana (again with a largely pro-BSP executive) has an exclusive polling contract with the state television company (which has a virtual monopoly over this media form). ${ }^{44}$ As a consequence, 
many opposition parties, commentators, and political activists allege that the BSP, BBSS, Mediana, and a number of media organizations have between them a virtual monopoly of the processes of polling information diffusion within Bulgaria, and significant scope therefore to manipulate the public through 'fake' or massaged polls. ${ }^{45}$ The criticism which the party, pollsters and media receive, whether warranted or not, has the effect of undermining the credibility of polls generally, as far as the public is concerned. In Romania, IRSOP have in the past been condemned on similar grounds for the polling research they have conducted for the ruling NSF in 1990 and 1991, and later, for the NDSFdominated government and Iliescu's presidential team.

The electorates' scepticism of party-polling is further undermined by the proliferation of (largely unknown) ad hoc 'ghost' pollsters during election campaign periods. This is a significant problem in Romania, where more established pollsters often claim that these 'ghost' agencies (which are usually linked to various political parties) have as their sole purpose to manipulate electoral outcomes and the general political process. Furthermore, they often place little store in the need for adopting rigorous scientific methods. According to Abraham, it is typical for such agencies to cite the failure of pollsters to predict electoral outcomes in countries like Britain (1992), Italy (1995), and France (1995) where polling is more established, as ultimately confirming the inherent limitations of polls, and as justification for themselves in producing findings which do not correspond with more mainstream polls. ${ }^{46}$ Thus, Kivu reports that in the 1992 Romanian general election period, there were about ten such fake polls produced by 'ghost' polling institutes, all utilizing non-rigorous methods (such as sample sizes of 100 respondents). One such poll suggested that the Greater Romania Party, scoring about $4 \%$ in most polls (and achieving 3.9\% in the election), had the support of $30 \%$ of the voters. ${ }^{47}$ A further example of the publics' scepticism of opinion polling can be found with reference to a Bulgarian electoral law which prohibits the publication of polls 14 days prior to an election, as well as the government ban on exit polls which has remained in place since the BSP election victory in 1990. In relation to the latter, the action was brought about when the opposition UDF mounted a campaign alleging procedural irregularities and fraud during the election, including a charge that the German polling institute INFAS had manipulated their findings in order to facilitate a bandwagon for the BSP, and falsify the elections. Ultimately, the UDF campaign culminated in a mass demonstration against electoral fraud, which won the support of the President, Zhelev. As part of the government's response to this campaign, exit polls were banned. ${ }^{48}$

\section{Polls and the Mass Media in Post-communist Countries}

A further way in which the development of polling in these new societies is mirroring liberal capitalist political systems, is in terms of the quantity (and as we shall see, the quality) of media-polling activities. In Hungary, media-pollster activities are particularly vigorous: 'Each newspaper has their 
own poll, and nearly everyday an opinion poll is reported, [conducted] by different companies. There are five companies producing polls for newspapers regularly, and about one hundred small ones' 49 Somogyi reports that television polling and secondary reporting of polls were common activities during the May 1990 general election in Hungary, where '...polls became a popular source of information'. ${ }^{50}$ However, in Poland, the restructuring of the media industry in 1990 led to the collapse of the RSW, a huge state-owned media group previously organized under the Communist Party, and a potential major investor in polls. The replacement of a state-controlled industry by a privatized industry guided by the free-market has led to a situation whereby a proliferation of small media companies, engaged in fierce competition with their rivals, and in a weak and vulnerable economic position, do not have the available resources to sponsor more than the occasional ad hoc public opinion poll. ${ }^{51}$ Nonetheless, the media-interest in, and reporting of opinion polls is substantial in these countries. Where there are formal associations with the media as sponsors of the polls, the pollsters themselves report that they are usually able to exert control over how the polls are devised, conducted, analyzed and reported. Evidence suggests that there is significant pollster autonomy from their media clients. Pollsters are usually confident that they are able to ensure that acceptable scientific standards of reliability are met in Hungary, Poland, (former) Czechoslovakia, Bulgaria and Romania for instance: there is close collaboration and negotiation with the clients on sample size and question-wording, and basic technical details are usually reported (sample size, number of sampling points, fieldwork dates and method, and size of the sampling error). This enables readers to judge the reliability of such polls.

One major area of concern with media-polls however, is the organizational and budgetary restrictions which the media impose on the pollsters. When combined, these impede the performance and accuracy of the polls, and ultimately undermine their credibility amongst the public. Nowotny claims for instance that it is usual practice in Poland for '....regular newspaper polls to be made very quickly - one day interviewing, and the next day the results. This type of survey is only possible with quota samples, not random samples. So the statistical parameters are not very strict' ${ }^{52}$ A further key problem is the lack of polling expertise amongst journalists in many of these countries. As a consequence, they often misinterpret, exaggerate or even distort the poll findings. In Romania, as with other post-communist countries, journalists typically have no training in (nor inclination to find out about) the usage and reporting of poll findings. ${ }^{53}$ They tend to have little understanding of social science empirical research, nor of the need for precision reporting, including the differences in findings from 'open' and 'closed' questions, question bias, and statistical significance; it is not uncommon for journalists to make what might appear to be merely basic typographical errors, but which in fact have significant statistical interpretation implications (such as the reporting of an 800 sample size poll as 8000 ). Often, the press will conduct their own polls. Muscetescu ${ }^{54}$ claims that 
there were many such polls in Romania during 1990, and these tended to ignore basic social science research convention. Problems arising from this included for instance the use of double-barreled ${ }^{55}$ and poorly structured questions, the over-sampling of easy-to-contact groups like intellectuals, and the under-sampling of groups which are more difficult to contact such as peasants. Datculescu ${ }^{56}$ criticizes the practice of the press to use 'coupon' polls ${ }^{57}$ where there is no control over sample selection, and which are both voluntary and subject to self-selection. These results are later reported in other newspapers, often as if they had been conducted by established opinion pollsters using methodical and rigorous scientific techniques.

Another major issue in the media's usage of opinion polls is the tendency to publish only findings which support a particular political inclination or ideological outlook. This is especially noticeable in the press. According to Herzmann, in (former) Czechoslovakia, 'Certain newspapers with a party bias or inclination, look for the data that fit their orientations' ${ }^{58}$ This practice is common elsewhere in Central and Eastern Europe. Muscetescu claims for instance that in Romania, the media often employ poll stories in order to strengthen their partisan positions; media output of polls depends more on what the data actually says, than how professionally or not it has been conducted. Consequently, there is overt political manipulation by the media (especially the press) of opinion polls. ${ }^{59}$ However, there is a growing tendency of the pollsters to assert their professionalism and independence vis-à-vis their media clients, and they often assist in the drafting of press reports. Nonetheless, the most important (and influential) aspect of media poll stories - the headline - is usually written by the journalist, with no input from the pollster.

The implications of selection, interpretation, and reporting of poll stories by the media on ideological grounds is given by Ivanov. He suggests that there are two important aspects of contemporary Bulgarian society which have the effect of making the public particularly susceptible to media-poll bias. The essence of these is likely to apply to other post-communist countries. Firstly, he proposes that one important legacy of communism is that of 'paternalism', one aspect of which includes the public having 'politics' explained to them by leaders. In the post-1989 context, this is reflected in the publics' tendency to look for opinion 'leaders' (politicians, the mass media, opinion pollsters) to help them make sense of politics. Consequently, in countries like Bulgaria, there is an absence of any completely independent opinion-making by the public - people are relatively easily influenced therefore by any poll they read. The second aspect of contemporary society therefore which contributes to the vulnerability of the public to manipulation is the misrepresentation or distortion of polling data by media organizations. This is likely to have a significant effect on public opinion formation, and as we have seen, is as common practice in post-communist societies as in liberal capitalist societies. The mass media organizations tend to present data in specific ways in order to promote their ideological positions and the parties which best represent them, and to 
encourage the salience of preferred political agendas. In Bulgaria, virtually all the newspapers have at least informal links with political parties, and this is common throughout Central and Eastern Europe. ${ }^{60}$ The scope for media-polls to influence the public, regardless of how objective and professional they were or were not conducted, is therefore significant in post-communist countries.

Furthermore, as is often the case in countries like Britain, journalists are often poorly trained in polling and psephology, tending to focus on headline polling data such as voting intention levels whilst ignoring other results. There is a tendency to sensationalize small changes in party support, without referring to or publishing the technical details (such as sampling error) which might help to point-up the minimalist nature of such findings, or bring to the readers' attention the qualifications which pollsters attach to the raw figures. Thus, in countries like Bulgaria, Romania, Poland, Hungary and (former) Czechoslovakia where the electorates' support is distributed amongst a multitude of competing parties, a one or two point change in a particular party's poll ratings is often reported by the media as indicating a significant development. It also tends to suggest to journalists and the public that there is major variation amongst the pollsters, demonstrating that the polls are unreliable. Where this is the case, Herzmann claims that: 'The public doubts if the polls present a 'real' picture of society. They wonder if we are lying, cheating or helping a political party'. ${ }^{61}$ This public scepticism of polls is reinforced by the tendency in some post-communist countries to treat poll issues as headline stories themselves, rather than as illustration of current affairs issues. Thus, in a research visit to Romania in May 1995 as part of this study, the daily newspaper Ziua (Today) reported a study which cast doubt on the credibility of the polling industry there, and received significant air-time on national statetelevision. On a front-page top-headline story, Ziua reported that a North American consultancy, Rowlands Research Team, had produced a 124-page report on the credibility and political independence of four of the leading polling agencies, and concluded that there was clear evidence of political complicity between IRSOP and the presidency. The headlines ${ }^{62}$ read:

Ziua Succeeded To Find Out Some Secrets From Washington. American Experts Demonstrated:

Iliescu Succeeded To Manipulate Us By IRSOP For Five Years

Datculescu's Company [IRSOP] Has The Lowest Degree Of Credibility, And The Highest Level of Political Dependency Among Romanian Public Opinion Institutions.

According to Romanian opinion pollsters, such stories are not untypical, and reflect a preoccupation with, and often discrediting of, pollsters by the media, especially if they have conducted work for political parties, movements or institutions anathema to that media organization. For instance, both Sandu (1995, vice-president of the Romanian Sociological Association) and Campeanu (1995, Director of the polling agency CIS) claim that the editor of Ziua is a former leading member of the Romanian Securitate, whose paper has formal links with the anti-Iliescu right-wing UDF. The newspaper article fails to consider basic questions with which to assess the validity of the study's 
findings, including: who Rowlands Research Team are; why they conducted the research; on whose behalf was the research undertaken; how the study was conducted; and what criteria were used to measure both credibility, and political independence.

As a consequence of such developments in the usage of polls by media organizations, the public has become increasingly sceptical of political opinion polls in many post-communist countries, because of the way they are used, and occasionally abused by the media and journalists.

\section{Conclusion}

What general conclusions can be drawn? In post-communist countries, polls have a valuable role to play for governments and political elites in terms of tapping into the publics' perceptions of the newly established political structures and political processes. According to McIntosh and Abele MacIver, this is important because these governments seek guidance through responding to citizens' views. ${ }^{63}$ Opinion polls therefore have a formal role to perform as a guide to both the nature of the political institutions and arrangements which the public consider should be developed, and to the social and economic policies which they believe should be pursued. There is also buoyant demand from political parties and the mass media (although the public is sceptical of close associations between the pollsters and such clients). It would be difficult to conclude however that these political agencies genuinely seek to use polls as tools through which to devolve power to civil society. Polls will usually be commissioned by various agencies in order to manipulate the public and the political process. The larger political parties commission polls with the same objectives in mind as their counter-parts in liberal capitalist countries like Britain, that is, to test their propaganda and to package their policies in ways which are electorally appealing to voters. ${ }^{64}$ Often, the relationship between these parties and the pollsters will be perceived as one of collusion by the public, and as a hangover from the communist era in which the pollsters were agents of the state, conducting propaganda through which to sustain the hegemony of dominant elites. ${ }^{65}$ The poor quality of media-sponsored and media-reported polls intensifies public scepticism of polling and contributes to a contradiction in the status of polling in these societies: on the one hand, the use of polls in the political process by the new regimes as a means of consulting with the public enhances the latter's positive views of polls, and ultimately improves the reliability of polls; on the other hand, the experiences of polling undertaken and/or utilized by parties and the mass media organizations serves to diminish both the public's confidence of and participation within opinion polls, and ultimately undermines the quality of polls.

There is significant scope for polls to strengthen and extend the processes of democratization, but polls will stop short of challenging the basis of elite power in society. Polls will inform the decision-making processes within different, competing elite groups, and compel these elites to respond to the demands of the citizenry. In this way, polls provide a channel through which the public can bring some pressure to bear on those who wield political power. Ultimately however, they do not 
help to wrest such power from the elites. In fact, the information which polls convey actually helps elites to compete for political power more effectively; in reality, polls reinforce the political hegemony of elites. Similarly, media-sponsored polls both contribute to, and undermine the democratic process. Media organizations enjoy relative freedom from the state to channel information about political affairs to the public. However, the manipulation of polling data by the mass media is such that the information can often be distorted, and there is significant potential for the public to be misinformed about political issues and events. Consequently, the public's capacity to make informed decisions about political affairs and hold elites accountable for their actions via the polls will be reduced. Opinion polls are therefore to be seen as double-edged weapons in the battle for democracy: they enable the public to channel their views to political elites, but the sponsors of the polls (the mass media organizations and various political elites) have significant capacity to design the polls, determine which questions are asked of the public, shape the political agenda, and influence both which political information is available for general consumption by the public, and what form it should take. Such developments suggest that the role of polls in European post-communist societies is one which is better understood in terms of Schumpeter's view of competitive elitism than Gallup's direct democracy model. 


\section{NOTES}

${ }^{1}$ For a discussion of the use of polls by British political parties in terms of their general campaigning, electioneering, and marketing, see Mark Abrams 'Public Opinion, Polls and Parties', Public Opinion Quarterly, Vol.27 (1963) pp.9-18, and 'Opinion Polls and Party Propaganda', Public Opinion Quarterly Vol.28 (1964) pp.13-19; Frank Teer and James D. Spence Political Opinion Polls (London: Hutchinson, 1973); Dennis Kavanagh 'Political Parties and Private Polls', in Robert Worcester and Martin Harrop (eds.) Political Communications: The General Election Campaign of 1979, (London: Allen and Unwin, 1982) pp.141-51, and 'Private Opinion Polls and Campaign Strategy', in Parliamentary Affairs, Vol.45, No.4 (1993) pp.518-27; Robert Worcester, British Public Opinion, (Oxford: Blackwell, 1991); David Broughton Public Opinion Polling and Politics in Britain (Hemel Hempstead: Harvester Wheatsheaf, 1995); Eric Shaw, 'Labour's Campaigning and Communications strategy 1987-92', Paper presented at the PSA Conference on The 1992 General Election: Voters, Parties and The Media, (September 1992); and the Nuffield British General Election series written by David Butler and various collaborating authors. The mass media is a particularly enthusiastic sponsor of political opinion polls, especially during election campaign periods (Worcester, 1991, op. cit.). Their utilization of polls however, has been subject to significant criticism, in terms of the constraints which they place upon pollsters and the impact this has on achieving methodological rigour (Sanford L. Weiner, 'The Competition for Certainty: The Polls and the Press in Britain', Political Science Quarterly, Vol.91, No.4 [Winter 1977] pp.673-96; Norman L. Webb and Robert J. Wybrow, 'Polls in a Changing World', in Worcester and Harrop, op. cit.), the ways in which they are employed (Irving Crespi, op. cit.; Daniel J. Boorstin, The Image: A Guide to Pseudo Events in America, [New York: Atheneum, 1961]), and the manner in which they are reported (Ivor Crewe, 'Saturation Polling, The Media and the 1983 Election', in Ivor Crewe and Martin Harrop [eds.] Political Communications: The General Election Campaign of 1983 [Cambridge: Cambridge University Press, 1986]; David Butler and Dennis Kavanagh, The British General Election of 1992, [London: MacMillan, 1992]). A further controversial means through which polls impinge upon the political process, is in terms of the way they are utilized by voters as sources of information about the state of popular support for competing political parties, especially during election campaign periods. One particularly durable criticism maintains that polls can help to determine electoral outcomes by defining what is and is not appropriate action or behaviour for voters, by 
fostering either a 'bandwagon', 'complacency', or 'underdog' effect (Herbert A. Simon, 'Bandwagon and Underdog Effects in Election Prediction', Models of man: Social and Rational [New York 1957]; Manfred Gartner, 'Endogenous Bandwagon and Underdog Effects', Public Choice, Vol.XXV [1976], pp.83-139; Philip D. Straffin, 'The Bandwagon Curve', American Journal of Political Science, Vol.XXI [1977], pp.695-709; Richard L. Henshel and William Johnston, 'The Emergence of Bandwagon Effects: A Theory', The Sociological Quarterly, Vol.28, No.4 [1987], pp.493-511; Cathy Marsh and John O’Brien, 'Opinion Bandwagons in Attitudes Towards the Common Market', Journal of the Market Research Society, Vol.31 [1989], pp.295-305; Ian McAllister and Donley Studlar, 'Bandwagon, Underdog or Projection? Opinion Polls and Electoral Choice in Britain 1979-1987', Journal of Politics, Vol.53 [1991], pp.720-41; Elisabeth NoelleNeumann, 'The Spiral of Silence: A Theory of Public Opinion', Journal of Communication, Vol.24 [1974] pp.43-51).

${ }^{2}$ For a review of polling under communism in these countries, see Piotr Kwiatkowski, 'Opinion Research and the Fall of Communism', International Journal of Public Opinion Research, Vol.4, No.4 (1992), pp.358-74; Jaroslaw A. Piekalkiewicz, Public Opinion in Czechoslovakia, 1968-69, (New York: Praeger, 1972); William A. Welsh (ed.) Survey Research and Public Attitudes in Eastern Europe and The Soviet Union, (New York: Pergamon, 1981); Walter D. Connor and Zvi Y. Gitelman, Public Opinion in European Socialist Systems (New York: Praeger, 1977); Matt Henn, 'Opinion Polling in Central and Eastern Europe Under Communism', Journal of Contemporary History, Forthcoming.

${ }^{3}$ The intention was to gain a sense of the changing conditions for opinion polling, and of the development of the industry in post-communist countries. Specifically, the objective was to add depth and clarity to issues which had emerged from a questionnaire survey of opinion pollsters conducted by the author between the end of 1990 and the beginning of 1993 (See Matt Henn 'Polls, Politics and Perestroika: The Emergence of Political Opinion Polling in Central and Eastern Europe', European Business and Economic Development, Vol.1, No.4 (1993), pp.11-17). The interviews took place during a series of field trips carried out in Poland, Hungary, and Czechoslovakia in 1991, and later in Bulgaria and Romania (1995). I would like to acknowledge the financial support given from both the Faculty of Economics and Social Sciences at the Nottingham Trent University, and from the British Councils in Warsaw and Budapest.

${ }^{4}$ J.A.Schumpeter, Capitalism, Socialism and Democracy, [London: Allen and Unwin 1976]. and p.269.

${ }^{5}$ Ibid, p. 250 
${ }^{6}$ George Gallup and Saul Rae, The Pulse of Democracy [New York: Simon and Schuster, 1940], p.8.

${ }^{7}$ Schumpeter, op.cit., p.269.

${ }^{8}$ Ibid, pp.256-68.

${ }^{9}$ Lindsay Rogers, The Pollsters, (New York: Knopf , 1949).

${ }^{10}$ Walter Lippmann, The Public Philosophy, (Boston: Little, Brown, 1955), p.32.

${ }^{11}$ Charles W.Roll and Albert H.Cantril, Polls, Their Use and Misuse in Politics (New York: Basic Books, 1972).

${ }^{12}$ Ibid, pp.143-44.

${ }^{13}$ Elisabeth Kiss-Schaeffer, GFK-Hungaria, Personal Interview, (Budapest, October 1995); Anna Somogyi, Mareco, Personal Interview, (Budapest, October 1991); Tamas Szecsko, HIPOR, Personal Interview, (Budapest, October 1991).

${ }^{14}$ Somogyi, op. cit.

${ }^{15}$ Petre Datculescu, IRSOP, Personal Interview, (Bucharest, May 1995).

${ }^{16}$ Miroslav Popov, Bulgarian Socialist Party, Personal Interview, (Sofia, May 1995).

${ }^{17}$ Jan Herzmann, IVVM, Personal Interview, (Prague, September 1991).

${ }^{18}$ Jan Hartl, STEM, Personal Interview, (Prague, October 1991).

${ }^{19}$ Piotr Kwiatkowski, CBOS, Personal Interview, (Warsaw, May 1991a).

${ }^{20}$ Stephan Nowotny, Demoskop, Personal Interview, (Warsaw, May 1991).

${ }^{21}$ Piotr Kwiatkowski, CBOS, Personal Interview, (Warsaw, May 1991b).

${ }^{22}$ An omnibus is a regular poll conducted by an institute, where clients pay to have particular questions put to the public (Somogyi, op. cit.; Jacek Dohnalik, OBOP, Personal Interview, [Warsaw, May 1991]; Marek Hoscalet, AISA, Personal Interview, [Prague, September 1991]).

${ }^{23}$ Hoscalet, op. cit.

${ }^{24}$ Anastassia Moser, Bulgarian Agrarian Party, Personal Interview, (Sofia, May 1995).

${ }^{25}$ See for instance Kavanagh, 1982, op. cit.

${ }^{26}$ Mircea Kivu, IMAS, Personal Interview, (Bucharest, May 1995).

${ }^{27}$ Bojun Gjuzelev, Bulgarian Democratic Party, Personal Interview, (Sofia, May 1995).

${ }^{28}$ Pavel Campeanu, CIS, Personal Interview, (Bucharest, May 1995).

${ }^{29}$ Kivu, op. cit. 
${ }^{30}$ Moser, op. cit.

${ }^{31}$ Gjuzelev, op. cit.; Moser, op. cit.

${ }^{32}$ Popov, op. cit.

${ }^{33}$ Gjuzelev, op. cit.

${ }^{34}$ Moser, op. cit.

${ }^{35}$ Somogyi, op. cit.

${ }^{36}$ Petre Datculescu, 'The Methodology of Pre-election Polls: Criteria of Accuracy and Credibility', Paper prepared for the International Meeting on 'Free and Fair Elections in Romania' 1993, (Sinaia 1992), p.1

${ }^{37}$ Ibid, p.29

${ }^{38}$ Dumitru Sandu, SOCIOBIT, Personal Interview, (Bucharest 1995).

${ }^{39}$ See Henry F. Carey, 'Irregularities or Rigging? The 1992 Romanian Parliamentary Elections', East European Quarterly, Vol.XXIX, No.1 (March 1995), pp.43-66.

${ }^{40}$ Other problems cited include: IMAS' reliance on postal surveys, which had a very low response rate; and the high percentage of 'undecideds' in all polls, whose demographics suggest they were likely to be Iliescu sympathizers (the polls by CIS were particularly sensitive to this problem, as they failed both to prompt this group, and to screen them out from the reported results).

${ }^{41}$ Sandu, op. cit.

${ }^{42}$ The historical roots of this relationship have been mentioned above.

${ }^{43}$ Data received from Ognian Shentov, Director of the Centre for the Study of Democracy, Sofia, May 1995

${ }^{44}$ Gjuzelev, op. cit.

${ }^{45}$ Gjuzelev, op. cit.; Moser, op. cit.; Andrei Ivanov, Centre for the Study of Democracy, Personal Interview, (Sofia, May 1995).

${ }^{46}$ Dorel Abraham, CURS, Personal Interview, (Bucharest, May 1995).

${ }^{47}$ Kivu, op. cit.

${ }^{48}$ Gjuzelev, op. cit.; Alexander Stoyanov, Centre for the Study of Democracy, Personal Interview, (Sofia, May 1995).

${ }^{49}$ Kiss-Schaeffer, op. cit.

${ }^{50}$ Somogyi, op. cit.

${ }^{51}$ Kwiatkowski, 1991b, op. cit. 
${ }^{52}$ Nowotny, op. cit.

${ }^{53}$ Abraham op. cit.; Kivu, op. cit.

${ }^{54}$ Muscetescu op. cit.

${ }^{55}$ Double-barreled questions include those where one question posed to respondents actually includes two or more non-mutually exclusive questions (such as 'How did you vote in the election?'. Here the respondent may be unsure as to which election is actually being referred to, and of course, they may have changed their vote at different elections.)

${ }^{56}$ Datculescu 1995, op. cit..

${ }^{57}$ Coupon polls are questions written into the newspapers themselves which readers are invited to complete, and then send back to the newspaper for analysis.

${ }^{58}$ Herzmann, op. cit.

${ }^{59}$ Muscetescu, op. cit.

${ }^{60}$ Ivanov, op. cit.

${ }^{61}$ Herzmann, op. cit.

${ }^{62}$ Translation by Sandu, and verified by Campeanu

${ }^{63}$ Mary E. McIntosh and Abele MacIver, 'Coping with Freedom and Uncertainty: Public Opinion in Hungary, Poland and Czechoslovakia 1989-1992', International Journal of Public Opinion Research, vol.4, No.4 (1992), pp.375-91.

${ }^{64}$ See Kavanagh, 1982 op. cit. and 1993 op. cit.

${ }^{65}$ See for instance, Kwiatkowski, 1992 op. cit; Henn, Forthcoming, op.cit. 